\title{
The role of epigenetics in personalized medicine: challenges and opportunities
}

\author{
Mahmood Rasool ${ }^{1,2^{*}}$, Arif Malik ${ }^{3}$, Muhammad Imran Naseer ${ }^{1}$, Abdul Manan $^{3}$, Shakeel Ahmed Ansari ${ }^{1}$, \\ Irshad Begum³ ${ }^{3}$ Mahmood Husain Qazi ${ }^{4}$, Peter Natesan Pushparaj ${ }^{1}$, Adel M Abuzenadah ${ }^{1,2}$, \\ Mohammed Hussein Al-Qahtani ${ }^{1}$, Mohammad Amjad Kamal ${ }^{5}$, Siew Hua Gan ${ }^{6}$
}

From 2nd International Genomic Medicine Conference (IGMC 2013)

Jeddah, Kingdom of Saudi Arabia. 24-27 November 2013

\begin{abstract}
Epigenetic alterations are considered to be very influential in both the normal and disease states of an organism. These alterations include methylation, acetylation, phosphorylation, and ubiquitylation of DNA and histone proteins (nucleosomes) as well as chromatin remodeling. Many diseases, such as cancers and neurodegenerative disorders, are often associated with epigenetic alterations. DNA methylation is one important modification that leads to disease. Standard therapies are given to patients; however, few patients respond to these drugs, because of various molecular alterations in their cells, which may be partially due to genetic heterogeneity and epigenetic alterations. To realize the promise of personalized medicine, both genetic and epigenetic diagnostic testing will be required. This review will discuss the advances that have been made as well as the challenges for the future.
\end{abstract}

\section{Introduction}

Modifications in gene expression that are independent of the DNA sequence of a gene are called epigenetic alterations. These alterations may contribute to epigenetic inheritance and epigenetic carcinogenesis or any other disease related to alterations in an organism. The epigenetic modifications and/or information are propagated transgenerationally to daughter cells through multiple somatic cell divisions (figure 1). An organism's genome can be modified by various chemical compounds or species in the biological system leading to changes in gene expression; these modifications are called the epigenome. Changes in the internal and external environment of a biological system, such as oxidative and nitrosative stress as well as nutritional changes, may lead to epigenetic alterations [1,2]. An organism's genotype has the ability to exhibit phenotypic variation caused by the influence of multiple environmental factors. This ability is called plasticity, and the most favorable form of plasticity occurs during development to

\footnotetext{
* Correspondence: mahmoodrasool@yahoo.com

${ }^{1}$ Center of Excellence in Genomic Medicine Research (CEGMR), King

Abdulaziz University, Jeddah, Saudi Arabia

Full list of author information is available at the end of the article
}

increase the survival rate and reproductive success of an organism [3].

Modifications in gene expression are controlled by these fundamental epigenetic mechanisms (figure 1): DNA methylation [4], histone modifications [4,5], chromatin remodeling and microRNAs that act as regulatory molecules [6]. These mechanisms regulate gene expression as well as various cellular and biological functions related to homeostasis, allostasis and disease. The phenotypic variations in humans caused by epigenetic modifications may lead to various diseases [7-9] including bone and skin diseases associated with autoimmune disorders [10], neurodegenerative diseases such as schizophrenia $[11,12]$ and cancer [13-16]. Therefore, traditional therapies may be ineffective to treat patients with epigenetic causes of disease. As a result, researchers are inclined to find patient-specific treatments for these patients, which are referred to as personalized or genomic medicines.

\section{Epigenetic modifications}

DNA methylation is considered to be one of the most important modifications leading to disease. Multiple processes, including gene expression, $\mathrm{X}$-chromosome inactivation, imprinting, chromatin organization and 


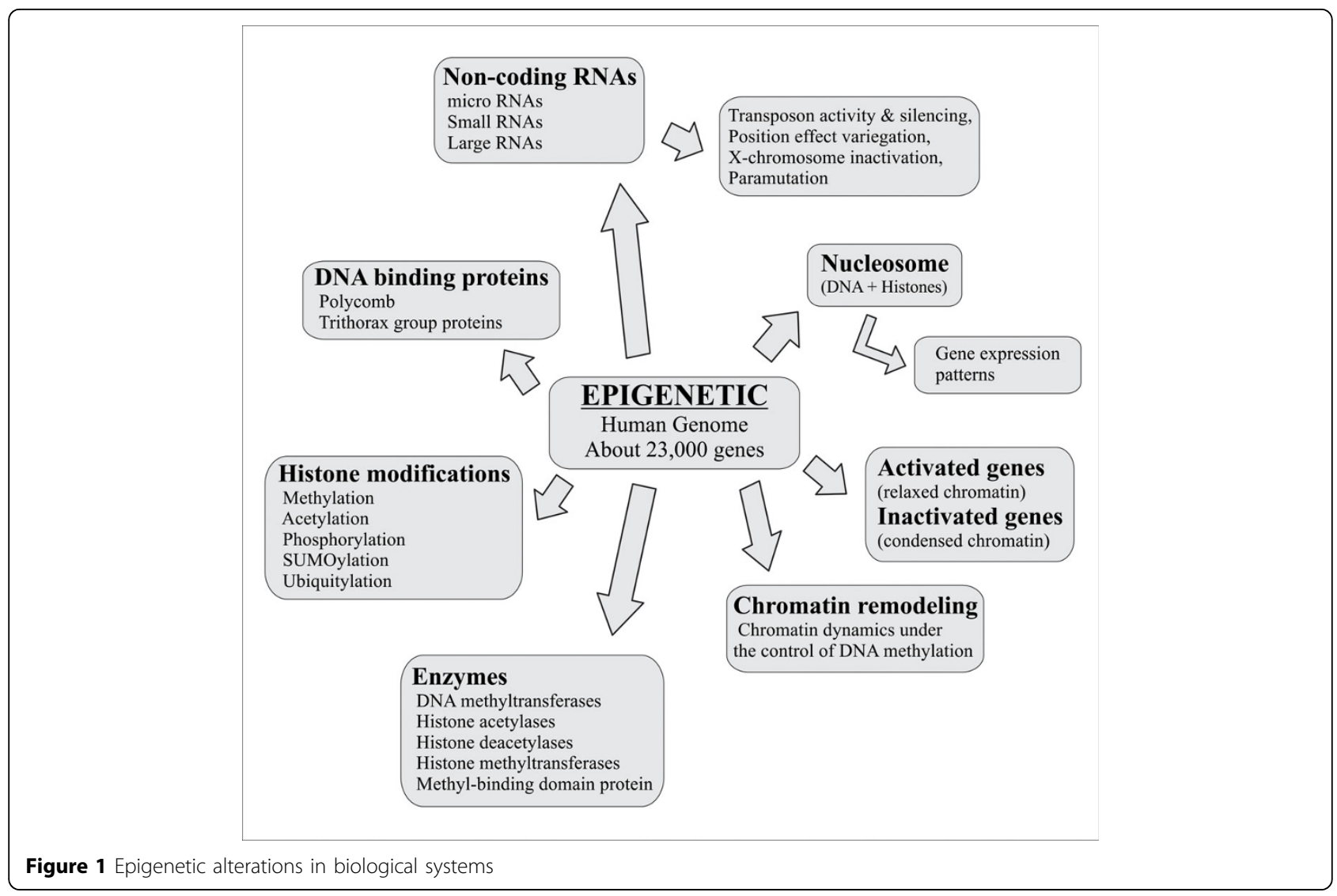

other biological processes are controlled by DNA methylation [4]. The addition of a methyl group $\left(-\mathrm{CH}_{3}\right)$ to cytosine frequently occurs at gene promoter regions with $\mathrm{CpG}$ islands, which are regions of large repetitive CpG dinucleotides occupying $60 \%$ of the promoter region [17]. Methylation of CpG dinucleotide(s) has been associated with disease states including cancer [18]. The enzymes responsible for DNA methylation are the DNA methyltransferases (DNMTs), which are categorized into five classes based on their specific enzymatic and physiological functions [4]. Another example of epigenetic modification is the modification of histones $[4,5]$, which occur through various nuclear, enzyme-catalyzed mechanisms that lead to modifications including methylation and acetylation of arginine and lysine [19], phosphorylation of threonine and serine, sumoylation of lysine, ubiquitination and ADP-ribosylation [6]. Multiple diseases such as Parkinson's disease, Angelman syndrome and mental retardation have been associated with ubiquitination (table 1). The acetylation of histone proteins at various amino acid residues is regulated by histone acetyltransferases (HATs) and histone deacetylases (HDACs) [18] (figure 1). The process of methylation occurs through the transfer of a methyl group to a histone from adenosyl methionine (AdoMet), and S-adenosylhomocysteine (AdoHcy) inhibits the action of DNMTs. AdoHcy hydrolase can hydrolyze AdoHcy into adenosine and homocysteine, and therefore, could be employed as a therapeutic agent for epigenetic diseases. Catalytic ATPases are involved in the energy driven alterations of nucleosome positioning and DNA-histone associations during the process of chromatin remodeling [[20], table 1].

\section{Genetic testing/screening}

The clinical utility of a medical test is determined by the ability of the test results to alter the decisions of physicians or the types of health care used to treat the disease. The diagnosis of a disease is based on signs and symptoms that may be indicative of several disorders in a biological system. At present, it is possible to determine the prognosis and diagnosis of any disorder through genetic testing or screening for disease-specific mutations. A large number of molecular biomarkers related to gene mutations can be identified through genomic studies. The results of prognostic and diagnostic tests using genomic data or DNA are used by health care professionals to diagnose disorders or diseases, to assess the risk of disease in an individual, to establish appropriate dosage for an individual based on variations 
Table 1 Multiple diseases related to ubiquitination.

\begin{tabular}{lllll}
\hline $\begin{array}{l}\text { Sr. } \\
\text { No. }\end{array}$ & Gene & Encodes for & Disorder & Citation \\
\hline $\mathbf{1}$ & Parkin & E3 ubiquitin ligase & Parkinson's disease (autosomal recess) & [21] \\
\hline $\mathbf{2}$ & uch/1 & $\begin{array}{l}\text { Ubiquitin C-terminal hydrolase } \\
\text { (UCH-L1) }\end{array}$ & Parkinson's disease (autosomal recess) & \\
\hline $\mathbf{3}$ & E6-AP & Ubiquitin ligase E6-AP (UBE3A) & Angelman syndrome & [21] \\
\hline $\mathbf{4}$ & $\begin{array}{l}\text { Single point mutation in } \\
\text { HUWE/Mule/ ARF-BP }\end{array}$ & $\begin{array}{l}\text { Ubiquitin ligase HUWE/Mule/ ARF- } \\
\text { BP }\end{array}$ & Mental retardation, X-linked, syndromic Turner type (MRXST) & [23,24] \\
\hline $\mathbf{5}$ & Ataxin-3 & Deubiquitinating enzyme, ataxin-3 & $\begin{array}{l}\text { Familial amyotrophic lateral sclerosis, Machado-Joseph } \\
\text { disease/ spinocerebellar ataxia type-3 }\end{array}$ & [25] \\
\hline $\mathbf{6}$ & Hippel Lindau vhl & E3-ubiquitin ligase & Pheochromocytoma (PCC) & [26] \\
\hline $\mathbf{7}$ & cyld & Deubiquitinase CYLD & Turban tumor syndrome (cylindromatosis) & [27] \\
\hline $\mathbf{8}$ & Aberrant expression/ & E3 ubiquitin ligase/ & Diverse types of cancer & \\
\hline & mutations & deubiquitinating enzymes (DUBs) & & \\
\hline
\end{tabular}

in metabolism and to determine whether an individual will benefit from a particular drug intervention for disease management.

On the other hand, personalized medicine is the application of an individual's personal genetic profile to predict disease, prevent disease through medical interventions, and make decisions about lifestyle and disease management based on the needs of each individual patient. Moreover, genetic screening is important for the personalization of treatment for a patient.

\section{Epigenetics and personalized/genomic medicine}

The study of the genome and its related information can shed light on various questions associated with the health and disease of an individual. Whole-genome DNA sequence information is now accessible due to the completion of the Human Genome Project (HGP). Specific drugs must be used for those patients who are not responding to traditional medicines as expected and for whom the rate of successful disease management is very low. Genomic or personalized medicines are given to patients after collecting genomic information and associated data such as the levels of RNA, proteins and various metabolites that are crucial factors in medical decision making for personalized medicine [31].

Genomic approaches such as the identification of DNA sequence variations, transcriptomics, proteomics and metabolomics are useful for precise disease management and prediction [32]. These approaches are useful tools that bridge epigenetics and personalized medicine: the human genome sequence (genomics) includes 10-15 million single nucleotide polymorphisms (SNPs) and copy number variants (CNVs); gene expression profiles (transcriptomics) consist of approximately 25,000 gene transcripts; the proteome (proteomics) includes approximately 100,000 specific protein products; and the metabolome (metabolomics) is a metabolic profile of 1000 to 10,000 metabolites [32].
Moreover, the information from an individual genome sequence and the associated expressed biomarkers also are imperative to achieve personalized and genomic therapies [33].

For a chronic disease, as traditional medicine or treatments may be ineffective for patients, the risk of disease may be inherited and reflect the patient's genomic background. While observing a patient from a healthy state to a diseased state, genomic applications can be used at various crucial checkpoints to personalize the individual's health care $[34,35]$.

\section{Pharmacogenomics and personalized medicines}

Pharmacogenomics deal with various biological factors related to drug metabolism including drug transporters, the contribution of receptors and drug metabolizing enzymes with polymorphisms that affect the drug response in a variety of diseases [36,37]; all of these parameters are under epigenetic control.

Pharmacogenomics help us to understand the idea of the precise and accurate drug for a respective patient at the accurate concentration and time. Moreover, it negates the concept of "one drug fits all." As far as multiple drug responses are concerned, various factors such as nutrition, age, body weight, sex, genetic behavior, infections, comedications and organ function are important considerations that are unavoidable during the course of treatment for a disease. Furthermore, the integration of relevant data associated with medical informatics and personalized medicines is highly targeted for the management of a disorder.

To understand variable drug responses (traditional and/ or personalized medicines), pharmacokinetics (PK) and pharmacodynamics (PD) are highly useful. These two disciplines integrate quantitative measurements of drug exposure and effect (figure 2). Pharmacokinetics data are associated with drug exposure and the monitoring of drug 


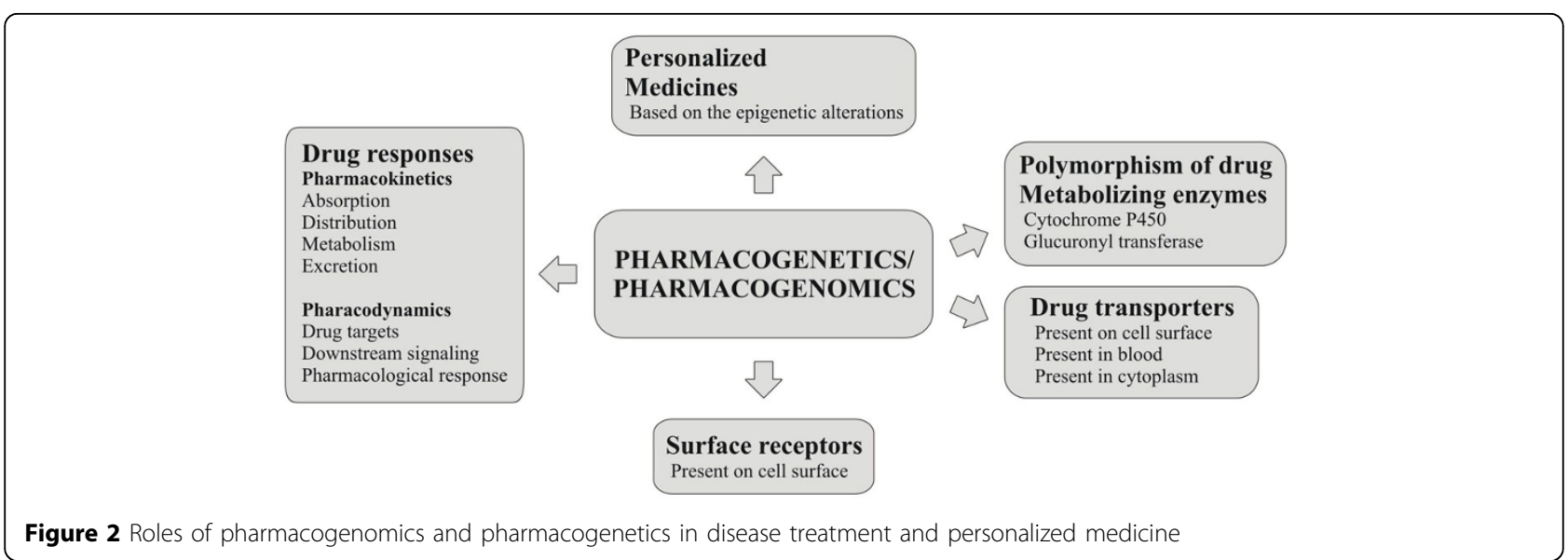

levels, providing a platform to analyze the phenotypic markers (epigenetic markers) useful for personalized medicine. Variability in drug response is often linked to alterations or mutations in the drug metabolizing enzymes cytochrome $\mathrm{P}_{450}$ and glucuronyl transferase, encoded by the polymorphic genes of the CYP450 family [38], as well as drug transporters encoded by several hundred genes [39]. Microarray technology can be used to detect the 29 known variants of two important CYP450 genes, CYP2D6 and CYP2C19; these genes affect the metabolism of $25 \%$ of all prescribed drugs [40].

Moreover, drug receptors are also encoded by polymorphic genes [39] and mutations in receptors, such as the receptor tyrosine kinases, have been linked to various cancers and neurodegenerative diseases [41-44]. For example, over-expression of ErbB2 (v-erb-b2 avian erythroblastic leukemia viral oncogene homolog 2) in breast cancer is treated with trastuzumab [43], the BCR/ABL fusion protein is highly sensitive to imatinib in the case of leukemia [41] and activating mutations of epidermal growth factor receptor (EGFR) seem to correlate with the responsiveness to gefitinib [42]. Hence, genotyping becomes very important for researchers to better understand a disease, its management and drug effects within the practice of personalized medicine. Once functional polymorphisms and genetic variability have been experimentally established for well-studied genes, this knowledge can be applied to future clinical studies.

Genetic variants are transcribed into mRNA and can affect its processing, including mRNA stability and alternative splicing. Studies have revealed that alternative splicing occurs in approximately $35-59 \%$ of all human genes [45]. Allelic expression has been analyzed based on mRNA expression and revealed that the catechol-O-methyltransferase gene (COMT) is a susceptibility gene for schizophrenia that is downregulated in the autopsy brain tissues of patients [46]. Epigenetic changes affect various disorders, including cancer and neurodegenerative diseases and their treatment outcomes [47-52]. Epigenetic and drug management data from disease patients are useful for the personalization of medicine.

Cancer classification is based on the histological analysis of tissues and/or cells. In the case of some tumors, such as leukemia and breast cancer, molecular biomarkers are used. Moreover, the mRNA expression profiles obtained through microarray analysis also contribute to the identification and classification of many cancers, such as colon, hematological and early stage breast cancers [53-59]. In the case of cancer, targeted therapy is based on gene alterations in specific cellular pathways, which aid the application of genomic medicine $[42,60]$.

Targeted cancer therapy involves tumor cell-specific treatments including monoclonal antibodies and small molecule inhibitors that are less toxic in their mode of action. This therapeutic strategy has opened new possibilities for cancer management. Several molecular targets and signaling pathways such as the aurora kinases, the FOXO-FOXM1 axis [61] and PI3K/mTOR signaling [62] are involved in human cancers. For example, the small molecule VX-680 shows an inhibitory effect and induces cell death in leukemic cells with a specific aurora expression profile by increasing the $\mathrm{Bax} / \mathrm{Bcl}-2$ ratio, which induces apoptosis in acute myeloid leukemia with high aurora-A expression [63].

Similarly, forkhead transcription factors (FOXO and FOXM1) play crucial roles in cell division, differentiation, angiogenesis, apoptosis, DNA repair and tissue homeostasis. Moreover, the FOXO-FOXM1 axis plays an important regulatory role in drug resistance and tumorigenesis [61].

\section{Current personalized medicines}

Some patients with late-stage non-small cell lung cancer (NSCLC) have rearrangements in the anaplastic lymphoma kinase $(A L K)$ gene, and conventional cancer therapies are ineffective for these patients (table 2). 
Table 2 Treatments and diagnostics of some selected personalized (genomic) medicine drugs*

\begin{tabular}{|c|c|c|c|}
\hline Sr. No. & Treatment & Genetic test/biomarker & Description \\
\hline 1 & Mivacurium & Cholinesterase gene & $\begin{array}{l}\text { Used for anesthesia adjunct, metabolized by plasma } \\
\text { cholinesterase }\end{array}$ \\
\hline 2 & Divalproex & $\begin{array}{l}\text { ornithine transcarbamylase deficiency } \\
\qquad(\mathrm{OTC})\end{array}$ & $\begin{array}{l}\text { Used in bipolar disorder, in patients with urea cycle disorders } \\
\text { (UCD); OTC }\end{array}$ \\
\hline 3 & Trastuzumab, Lapatinib & $\begin{array}{l}\text { Human epidermal growth factor receptor- } \\
2 \text { (HER2)/neu receptor }\end{array}$ & Patients with metastatic breast cancer \\
\hline 4 & Warfarin & Cytochrome P450 (CYP2C9) & $\begin{array}{c}\text { Used in cardiovascular diseases (CVD), patients with CYP2C9*2 } \\
\text { and CYP2C } 9^{*} 3 \text { alleles }\end{array}$ \\
\hline 5 & Warfarin & VKORC1 & $\begin{array}{c}\text { Used in cardiovascular diseases (CVD), single nucleotide } \\
\text { polymorphism in VKORC1 gene }\end{array}$ \\
\hline 6 & Atorvastatin & $L D L R$ & $\begin{array}{c}\text { Used in cardiovascular diseases (CVD), homozygous familial } \\
\text { hypercholesterolemia and heterozygous }\end{array}$ \\
\hline 7 & Irinotecan & UGTIA1 & Used in colon cancer, homozygous condition for UGTIA $1^{*} 28$ \\
\hline 8 & Cetuximab, Panitumumab & EGFR expression & Used in colon cancer \\
\hline 9 & Carbamazepine & $H L A-B^{*} 1502$ & Used in epilepsy and bipolar disorder \\
\hline 10 & Abacavir & $H L A-B * 5701$ & Used in human immunodeficiency syndrome (HIV) \\
\hline 11 & $\begin{array}{c}\text { Mercaptopurine, } \\
\text { thioguanine, azathioprine }\end{array}$ & $\begin{array}{c}\text { Thiopurine S-methyltransferase (TPMT) } \\
\text { test }\end{array}$ & Used in leukemia \\
\hline 12 & Chloroquine & $\begin{array}{l}\text { Glucose 6-dehydrogenase deficiency } \\
\text { (G6PD) test }\end{array}$ & Used in malaria \\
\hline 13 & Capecitabine & $\begin{array}{l}\text { Dihydropyrimidine dehydrogenase (DPD) } \\
\text { activity test }\end{array}$ & Used in multiple cancers \\
\hline 14 & $5-\mathrm{FU}$ & $\begin{array}{l}\text { Dihydropyrimidine dehydrogenase (DPD) } \\
\text { activity test }\end{array}$ & Used in skin cancer \\
\hline 15 & Trastuzumab, Lapatinib & $\begin{array}{l}\text { Human epidermal growth factor receptor- } \\
2 \text { (HER2)/neu receptor }\end{array}$ & Used in stomach cancer \\
\hline 16 & Imatinib & $\begin{array}{l}\text { Platelet derived growth factor receptor } \\
\text { (PDGFR) gene }\end{array}$ & Used in myelodysplastic syndrome \\
\hline 17 & Lenalidomide & $5 q$ deletion & Used in myelodysplastic syndrome \\
\hline 18 & Celecoxib & CYP2C9 & $\begin{array}{c}\text { Used in pain, patients suspected to be } P 4502 \text { C9 poor } \\
\text { metabolizers }\end{array}$ \\
\hline
\end{tabular}

* This list and further details relating to these drugs can be found at the FDA's website (http://www.fda.gov/drugs/scienceresearch/researchareas/ pharmacogenetics/ucm083378.htm).

Hence, crizotinib (Xalkori $\left.{ }^{\circledR}\right)$, an anti-cancer drug that inhibits ROS1 (c-ros oncogene 1) and ALK, is used for the $5 \%$ of patients that will respond to this drug because they have a chromosomal rearrangement that produces a gene fusion (ALK and EML4, echinoderm microtubuleassociated protein-like 4) that results in carcinogenesis. Genetic tests are recommended for multiple diseases that could be treated with personalized medicine; there are approximately 1,600 molecular diagnostic tests available that target multiple disorders [64]. Many patients do not respond to first-line therapies, and studies have shown that this lack of response is due to differences in the genes that encode drug targets, transporters and metabolizing enzymes such as cytochrome $\mathrm{P}_{450}$ and glucuronyl transferase [65-67].

For various types of cancers, molecular diagnoses are available that assist physicians in improving disease management and increasing the chance of patient survival (table 2). For example, melanoma cases are classified based on the results of the $B R A F$ genetic test. Moreover, non-small cell lung cancers can test positive for $A L K$ and $B R A F$ mutations, which is useful for targeting the $A L K$ and $B R A F$ gene alterations during the course of molecular treatment [68].

Different cancers exhibit different rates of genetic mutations that drive carcinogenesis: melanoma has the highest rate of genetic mutation (73\%), while thyroid cancer has the second highest (56\%). Following these cancers in driver mutation prevalence are lung cancer at $41 \%$, gynecological cancers at $31 \%$ andgastrointestinal cancers at $25 \%$ and both ovarian and head and neck cancers at $21 \%$ [68]. For example, patients with mutations in the BRCA1 or $B R C A 2$ genes have a 36 to $85 \%$ chance of developing breast cancer compared with a $13 \%$ risk among the general female population $[69,70]$. In breast cancer cases, approximately $30 \%$ of cancers exhibit over-expression of the cell surface protein known as human epidermal growth factor receptor 2 (HER2), and the standard therapy 
is not effective in these HER2-overexpressing patients (table 2). However, the antibody drug trastuzumab can decrease the recurrence of HER2-positive tumors by $52 \%$ when combined with chemotherapy, a response greater than that for chemotherapy alone [71,72]. While patients with metastatic colon cancer with a KRAS mutation could be treated with cetuximab $\left(\right.$ Erbitux $^{\circledR}$ ) and panitumumab $\left(\right.$ Vectibix $\left.^{\mathbb{B}}\right)$, it is recommended that only patients with a normal KRAS gene be treated with these drugs in combination with chemotherapy $[73,74]$.

\section{Conclusion}

A given genotype has the ability to confer a variety of phenotypes in the presence of different environmental factors; this ability is called plasticity. Modifications in gene expression are controlled by fundamental epigenetic mechanisms including DNA methylation, histone modifications, chromatin remodeling and microRNAs that act as regulatory molecules. Various tools are used to identify phenotypic or epigenetic alterations in biological systems. Such environmentally influenced alterations may lead to several disorders and patients with epigenetic alterations and their associated disorders do not respond to conventional therapy. Therefore, drugs used for personalized medicine can be used to manage these disorders based on an individual's personal genomic profile. Many of the drugs used for personalized medicine have been approved by the FDA. However, various challenges exist for the scientists and researchers studying genomic alterations and their phenotypic expression given that each patient is unique.

\section{List of abbreviations \\ DNA: deoxyribonucleic acid; - $\mathrm{CH}_{3}$ : methyl group; DNMTs: Methyltransferases; HAT: histone acetyltransferases; HDAC: histone deacetylases; AdoMet: adenosyl methionine; AdoHcy: Adenosylhomocysteine; HGP: Human Genome Project; SNPs: single nucleotide polymorphisms; CNVs: copy number variants; PK: Pharmacokinetics; PD: Pharmacodynamics; CYP450: cytochrome $\mathrm{P}_{450}$; EGFR: epidermal growth factor receptor; ErbB2: v-erb-b2 avian erythroblastic leukemia viral oncogene homolog 2; COMT: catechol-O- methyltransferase; FOXO, FOXM1: forkhead transcription factors; NSCLC: non- small cell lung cancer; $A L K$ : anaplastic lymphoma kinase; EML4: echinoderm microtubule-associated protein-like 4; BRAF: v-RAF murine sarcoma viral oncogene homolog B1; HER2: human epidermal growth factor receptor 2.}

\section{Conflict of interest}

The authors declare that they have no competing interests.

\section{Authors' Contribution}

Rasool M, Malik A, Naseer MI, Manan A, searched the literature using various internet tools and wrote the manuscript. Ansari SA, Begum I, Qazi MH, Pushparaj PN,analyzed the data and reviewed the manuscript critically. Abuzenadah AM, Kamal MA, Gan SH, significantly contributed in final editing to improve the quality of the manuscript. Al-Qahtani MH approved the final manuscript for publication.

\section{Acknowledgement}

The authors would like to thank the facilities provided by the King Abdulaziz University, the University of Lahore and the Universiti Sains Malaysia. Publication fees has been paid by Centre of Excellence in Genomic Medicine
Research (CEGMR), King Abdulaziz University, KSA. MR is supported by KACST Strategic Project code: 12-MED3078-03. PNP is funded by KACST Strategic Project Codes: 12-BIO2719-03 and 12-BIO2267-03". MIN is funded by KACST Strategic Project Codes: 12-BIO3059-03 and APR-34-13.

\section{Declarations}

This article has been published as part of BMC Medical Genomics Volume 8 Supplement 1, 2015: Selected articles from the 2 nd International Genomic Medical Conference (IGMC 2013): Medical Genomics. The full contents of the supplement are available online at http://www.biomedcentral.com/ bmcmedgenomics/supplements/8/S1

\section{Authors' details}

${ }^{1}$ Center of Excellence in Genomic Medicine Research (CEGMR), King Abdulaziz University, Jeddah, Saudi Arabia. ${ }^{2}$ KACST Technology Innovation Center in Personalized Medicine, King Abdulaziz University, Jeddah, Kingdom of Saudi Arabia. ${ }^{3}$ Institute of Molecular Biology and Biotechnology, (IMBB), the University of Lahore, Lahore, Pakistan. ${ }^{4}$ Center for Research in Molecular Medicine (CRiMM), The University of Lahore, Pakistan. ${ }^{5}$ King Fahd Medical Research Center, King Abdulaziz University, Jeddah, Saudi Arabia. ${ }^{6}$ Human Genome Centre, School of Medical Sciences, Universiti Sains Malaysia, 16150 Kubang Kerian, Kelantan, Malaysia.

Published: 15 January 2015

\section{References}

1. Heijmans BT, Tobi EW, Stein AD, Putter H, Blauw GJ, Susser ES, Slagboom PE, Lumey LH: Persistent epigenetic differences associated with prenatal exposure to famine in humans. Proc Natl Acad Sci 2008, 105:17046-17049.

2. McGowan PO, Sasaki A, D'Alessio AC, Dymov S, Labonté B, Szyf M, Turecki G, Meaney MJ: Epigenetic regulation of the glucocorticoid receptor in human brain associates with childhood abuse. Nat Neurosci 2009, 12:342-348.

3. Jirtle RL, Skinner MK: Environmental epigenomics and disease susceptibility. Nat Rev Genet 2007, 8:253-262.

4. Sadikoric B, Al-Romaih K, Squire JA, Zielinske M: Causes and Consequences of Genetic and Epigenetic Alterations in Human Cancer. Current Genomic 2008, 9:394-408.

5. Mikkelson TS: Genome-wide maps of chromatin state in Pluripotent and Lineage-committed cells. Nature 2007, 448:553-560.

6. Choi SW, Friso S: Epigenetics: A New Bridge between Nutrition and Health. American society for Nutrition. Adv Nutr 2010, 1:8-16.

7. Hirst M, Marra MA: Epigenetics and human disease. Int J Biochem Cell Biol 2009, 41:136-146.

8. Feinberg AP: Phenotypic plasticity and the epigenetics of human disease. Nature 2007, 447:433-440.

9. Bjornsson $H T$, Fallin MD, Feinberg AP: An integrated epigenetic and genetic approach to common human disease. Trends Genet 2004, 20:350-358.

10. Richardson B: Primer: epigenetics of autoimmunity. Nat Clin Pract Rheumatol 2007, 3:521-527.

11. Mehler MF: Epigenetics and the nervous system. Ann Neurol 2008, 64:602-617.

12. Petronis $A$ : The origin of schizophrenia: genetic thesis, epigenetic antithesis, and resolving synthesis. Biol Psychiatry 2004, 55:965-970

13. Esteller M: Epigenetics in cancer. N Engl J Med 2008, 358:1148-1159.

14. Feinberg AP, Tycko B: The history of cancer epigenetics. Nat Rev Cancer 2004, 4:143-153.

15. Esteller M: Cancer epigenomics: DNA methylomes and histonemodification maps. Nat Rev Genet 2007, 8:286-298.

16. Jones PA, Baylin SB: The epigenomics of cancer. Cell 2007, 128:683-692.

17. Wang $Y$ : An evaluation of new criteria for $\mathrm{CpG}$ islands in the human genome as gene markers. Bioinformatics 2004, 20:1170-1177.

18. Momparler RL: Cancer Epigenetics. Oncogene 2003, 22:6479-6483.

19. Chang $X$, Blumenthal RM: Coordinated chromatin control: Structural and Functional linkage of DNA and histone methylation. Biochemistry 2010, 49:2999-3008.

20. Kim JK, Samaranayake M, Pradhan S: Epigenetic mechanisms in mammals. Cell Mol Life Sci 2009, 66:596-612. 
21. Corti O, Lesage S, Brice A: What genetics tells us about the causes and mechanisms of Parkinson's disease. Physiol Rev 2011, 91:1161-1218.

22. Malzac P, Webber H, Moncla A, Graham JM, Kukolich M, Williams C, Pagon RA, Ramsdell LA, Kishino T, Wagstaff J: Mutation analysis of UBE3A in Angelman syndrome patients. Am J Hum Genet 1998, 62:1353-1360.

23. Parsons JL, Tait PS, Finch D, Dianova II, Edelmann MJ, Khoronenkova SV, Kessler BM, Sharma RA, McKenna WG, Dianov GL: Ubiquitin ligase ARFBP1/Mule modulates base excision repair. EMBO J 2009, 28:3207-3215.

24. Froyen $\mathrm{G}$, Corbett M, Vandewalle J, Jarvela I, Lawrence O, Meldrum C, Bauters M, Govaerts K, Vandeleur L, Van Esch H, Chelly J, Sanlaville D, van Bokhoven H, Ropers HH, Laumonnier F, Ranieri E, Schwartz CE, Abidi F, Tarpey PS, Futreal PA, Whibley A, Raymond FL, Stratton MR, Fryns JP, Scott R, Peippo M, Sipponen M, Partington M, Mowat D, Field M, Hackett A, Marynen P, Turner G, Gécz J: Submicroscopic duplications of the hydroxysteroid dehydrogenase HSD17B10 and the E3 ubiquitin ligase HUWE1 are associated with mental retardation. Am J Hum Genet 2008, 82:432-443.

25. Tzvetkov N, Breuer P: Josephin domain-containing proteins from a variety of species are active de-ubiquitination enzymes. Biol Chem 2007, 388:973-978.

26. Latif F, Tory K, Gnarra J, Yao M, Duh FM, Orcutt ML, Stackhouse T, Kuzmin I, Modi W, Geil L: Identification of the von Hippel-Lindau disease tumor suppressor gene. Science 1993, 260:1317-1320

27. Bignell GR, Warren W, Seal S, Takahashi M, Rapley E, Barfoot R, Green H, Brown C, Biggs PJ, Lakhani SR: Identification of the familial cylindromatosis tumour-suppressor gene. Nat Genet 2000, 25:160-165.

28. Marine JC: Spotlight on the role of COP1 in tumorigenesis. Nat Rev Cancer 2012, 12:455-464.

29. Fraile JM, Quesada V, Rodriguez D, Freije JM, Lopez-Otin C: Deubiquitinases in cancer: new functions and therapeutic options. Oncogene 2012, 31:2373-2388.

30. Hussain S, Zhang Y, Galardy PJ: DUBs and cancer: the role of deubiquitinating enzymes as oncogenes, non-oncogenes and tumor suppressors. Cell Cycle 2009, 8:1688-1697.

31. Ginsburg GS, Willard HF: Genomic and personalized medicine: foundations and applications. Translational Research 2009, 154:277-287.

32. Willard $\mathrm{H}$ : Organization, variation and expression of the human genome as a foundation of genomic and personalized medicine. In Genomic and personalized medicine.. 1 edition. Durham, NC: Elsevier;Willard H, Ginsburg GS 2009:

33. West M, Ginsburg GS, Huang A, Nevins J: Embracing the complexity of genomic data for personalized medicine. Genome Res 2006, 16:559-566.

34. Ginsburg GS, McCarthy J: Personalized medicine and the pharmaceutical industry. Trends Biotechnol 2001, 19:491-496.

35. Willard H, Angrist M, Ginsburg G: Genomic medicine: Genetic variation and its impact on the future of health care. Phil Trans R Soc B 2005, 360:1543-1550.

36. Pirmohamed M: Pharmacogenetics: Past, present and future. Drug Discov Today 2011, 16:852-861.

37. Snyderman R: The role of genomics in enabling prospective health care. In Genomic and personalized medicine. Durham, NC: Elsevier;Willard H, Ginsburg GS 2009:378-385.

38. Phillips KA, Veenstra DL, Oren E, Lee JK, Sadee W: Potential role of Pharmacogenomics in reducing adverse drug reactions: a systematic review. JAMA 2001, 286:2270-2279.

39. Huang Y, Anderle P, Bussey KJ, Barbacioru C, Shankavaram U, Dai Z, Reinhold WC, Papp A, Weinstein JN, Sadee W: Membrane transporters and channels: role of the transportome in cancer chemosensitivity and chemoresistance. Cancer Res 2004, 64:4294-4301.

40. Jain KK: Applications of AmpliChip ${ }^{\circledR}$ CYP450. Mol Diag 2005, 9:119-127.

41. Druker BJ, Talpaz M, Resta DJ, Peng B, Buchdunger E, Ford JM, Lydon NB, Kantarjian H, Capdeville R, Ohno-Jones S, Sawyers CL: Efficacy and safety of a specific inhibitor of the BCR-ABL tyrosine kinase in chronic myeloid leukemia. N Engl J Med 2001, 344:1031-1037.

42. Lynch TJ, Bell DW, Sordella R, Gurubhagavatula S, Okimoto RA, Brannigan BW, Harris PL, Haserlat SM, Supko JG, Haluska FG, Louis DN, Christiani DC, Settleman J, Haber DA: Activating mutations in the epidermal growth factor receptor underlying responsiveness of nonsmall-cell lung cancer to gefitinib. N Engl J Med 2004, 350:2129-2139.

43. Slamon DJ, Leyland-Jones B, Shak S, Fuchs H, Paton V, Bajamonde A, Fleming T, Eiermann W, Wolter J, Pegram M, Baselga J, Norton L: Use of chemotherapy plus a monoclonal antibody against HER2 for metastatic breast cancer that over-expresses HER2. N Engl J Med 2001, 344:783-792.

44. Rasool M, Malik A, Qazi A, Sheikh IA, Manan A, Shaheen S, Qazi MH, Chaudhary AG, Abuzenadah AM, Asif M, Alqahtani MH, lqbal Z, Shaik MM, Gan SH, Kamal MA: Current View from Alzheimer Disease to Type 2 Diabetes Mellitus. CNS Neurol Disord Drug Targets 2014, 13(3):533-42.

45. Modrek B, Lee C: A genomic view of alternative splicing. Nat Genet 2002, 30:13-19.

46. Bray NJ, Buckland PR, Williams NM, Williams HJ, Norton N, Owen MJ O'Donovan MC: A haplotype implicated in schizophrenia susceptibility is associated with reduced COMT expression in human brain. Am J Hum Genet 2003, 73:152-161.

47. Petronis A: Epigenetics and bipolar disorder: new opportunities and challenges. Am J Med Genet 2003, 123:65-75.

48. Rakyan VK, Blewitt ME, Druker R, Preis JI, Whitelaw E: Metastable epialleles in mammals. Trends Genet 2002, 18:348-351.

49. Laird PW: Cancer epigenetics. Hum Mol Genet 2005, 14:65-76.

50. Byrd JC, Marcucci G, Parthun MR, Xiao JJ, Klisovic RB, Moran M, Lin TS, Liu S, Sklenar AR, Davis ME: A phase 1 and pharmacodynamic study of depsipeptide (FK228) in chronic lymphocytic leukemia and acute myeloid leukemia. Blood 2005, 105:959-967.

51. Dowell JE, Minna JD: Cancer chemotherapy targeted at reactivating the expression of epigenetically inactivated genes. J Clin Oncol 2004, 22:1353-1355.

52. Esteller M, Garcia-Foncillas J, Andion E, Goodman SN, Hidalgo OF, Vanaclocha V, Baylin SB, Herman JG: Inactivation of the DNA-repair gene MGMT and the clinical response of gliomas to alkylating agents. $N$ Engl J Med 2000, 343:1350-1354.

53. Rosenwald A, Wright G, Chan WC, Connors JM, Campo E, Fisher RI, Gascoyne RD, Muller-Hermelink HK, Smeland EB, Giltnane JM, Hurt EM, Zhao $H$, Averett $L$, Yang L, Wilson WH, Jaffe ES, Simon R, Klausner RD, Powell J, Duffey PL, Longo DL, Greiner TC, Weisenburger DD, Sanger WG, Dave BJ, Lynch JC, Vose J, Armitage JO, Montserrat E, López-Guillermo A, Grogan TM, Miller TP, LeBlanc M, Ott G, Kvaloy S, Delabie J, Holte H, Krajci P, Stokke T, Staudt LM: The use of molecular profiling to predict survival after chemotherapy for diffuse large-B-cell lymphoma. $N$ Engl J Med 2002, 346:1937-1947.

54. Van't Veer LJ, Dai H, Van de Vijver MJ, He YD, Hart AA, Mao M, Peterse HL, van der Kooy K, Marton MJ, Witteveen AT, Schreiber GJ, Kerkhoven RM, Roberts C, Linsley PS, Bernards R, Friend SH: Gene expression profiling predicts clinical outcome of breast cancer. Nature 2002, 415:530-536.

55. Paik S, Shak S, Tang G, Kim C, Baker J, Cronin M, Baehner FL, Walker MG, Watson D, Park T, Hiller W, Fisher ER, Wickerham DL, Bryant J, Wolmark N: A multigene assay to predict recurrence of tamoxifen-treated, nodenegative breast cancer. N Engl J Med 2004, 351:2817-2826.

56. Wang Y, Klijn JG, Zhang Y, Sieuwerts AM, Look MP, Yang F, Talantov D, Timmermans M, Meijer-van Gelder ME, Yu J, Jatkoe T, Berns EM, Atkins D, Foekens JA: Gene-expression profiles to predict distant metastasis of lymph-node-negative primary breast cancer. Lancet 2005, 365:671-679.

57. Dave SS, Fu K, Wright GW, Lam LT, Kluin P, Boerma EJ, Greiner TC, Weisenburger DD, Rosenwald A, Ott G, Müller-Hermelink HK, Gascoyne RD Delabie J, Rimsza LM, Braziel RM, Grogan TM, Campo E, Jaffe ES, Dave BJ, Sanger W, Bast M, Vose JM, Armitage JO, Connors JM, Smeland EB, Kvaloy S, Holte H, Fisher RI, Miller TP, Montserrat E, Wilson WH, Bahl M, Zhao H, Yang L, Powell J, Simon R, Chan WC, Staudt LM: Molecular diagnosis of Burkitt's lymphoma. N Engl J Med 2006, 354:2431-2442.

58. Lo SS, Mumby PB, Norton J, Rychlik K, Smerage J, Kash J, Chew HK, Gaynor ER, Hayes DF, Epstein A, Albain KS: Prospective multi-center study of the impact of the 21-gene recurrence score assay on medical oncologist and patient adjuvant breast cancer treatment selection. J Clin Oncol 2010, 28:1671-1676.

59. O'Connell MJ, Lavery I, Yothers G, Paik S, Clark-Langone KM, Lopatin M, Watson D, Baehner FL, Shak S, Baker J, Cowens JW, Wolmark N: Relationship between tumor gene expression and recurrence in four independent studies of patients with stage II/III colon cancer treated with surgery alone or surgery plus adjuvant fluorouracil plus leucovorin. J Clin Oncol 2010, 28:3937-3944

60. Paez JG, Jänne PA, Lee JC, Tracy S, Greulich H, Gabriel S, Herman P, Kaye FJ, Lindeman N, Boggon TJ, Naoki K, Sasaki H, Fujii Y, Eck MJ, Sellers WR, Johnson BE, Meyerson M: EGFR mutations in lung cancer: Correlation with clinical response to gefitinib therapy. Science 2004, 304:1497-1500. 
61. Gomes AR, Zhao F, Lam EWF: Role and regulation of the forkhead transcription factors FOXO3a and FOXM1 in carcinogenesis and drug resistance. Chin J Cancer 2013, 32:366-371.

62. Maria $\mathrm{E}$, Gil C: Targeting the PI3K/AKT/mTOR pathway in estrogen receptor-positive breast cancer. Cancer treatment reviews 2014, 10.1016/j. ctrv.2014.03. 004

63. Yan M, Liu QQ: Targeted therapy: tailoring cancer treatment. Chin J Cancer 2013, 32(7):363-364.

64. Couzin-Frankel J: NIH Wants to Hear About Genetic Tests. Science Insider 2010

65. Mangravite LM, Thorn CF, Krauss RM: Clinical implications of pharmacogenomics of statin treatment. Pharmacogenomics J 2006, 6:360-74.

66. Terra SG, Hamilton KK, Pauly DF, Lee CR, Patterson JH, Adams KF, Schofield RS, Belgado BS, Hill JA, Aranda JM, Yarandi HN, Johnson JA: Beta1-adrenergic receptor polymorphisms and left ventricular remodeling changes in response to beta-blocker therapy. Pharmacogenet Genomics 2005, 15:227-234.

67. Rieder MJ, Reiner AP, Gage BF, Nickerson DA, Eby CS, McLeod HL, Blough DK, Thummel KE, Veenstra DL, Rettie AE: Effect of VKORC1 haplotypes on transcriptional regulation and warfarin dose. N Engl J Med 2005, 352:2285-2293

68. Winslow R: Major shift in war on cancer. Wall Street Journal 2011.

69. Ries LAG, Harkins D, Krapcho M, et al: SEER Cancer Statistics Review, 19752003. National Cancer Institute; Available online at: http://www.seer.cancer. gov/csr/1975_2003/.

70. National Cancer Institute BRCA1 and BRCA2 fact sheet. NCl website, Available at: http://www.cancer.gov/cancertopics/factsheet/risk/brca

71. Piccart-Gebhart MJ, Procter M, Leyland-Jones B, Goldhirsch A, Untch M, Smith I, Gianni L, Baselga J, Bell R, Jackisch C, Cameron D, Dowsett M, Barrios CH, Steger G, Huang CS, Andersson M, Inbar M, Lichinitser M, Láng I, Nitz U, Iwata H, Thomssen C, Lohrisch C, Suter TM, Rüschoff J, Suto T, Greatorex V, Ward C, Straehle C, McFadden E, Dolci MS, Gelber RD: Trastuzumab after adjuvant chemotherapy in HER2-positive breast cancer. N Engl J Med 2005, 353:1659-1672.

72. Romond EH, Perez EA, Bryant J, Suman VJ, Geyer CE Jr, Davidson NE, TanChiu E, Martino S, Paik S, Kaufman PA, Swain SM, Pisansky TM, Fehrenbacher L, Kutteh LA, Vogel VG, Visscher DW, Yothers G, Jenkins RB, Brown AM, Dakhil SR, Mamounas EP, Lingle WL, Klein PM, Ingle JN, Wolmark N: Trastuzumab plus adjuvant chemotherapy for operable HER2-positive breast cancer. N Engl J Med 2005, 353:1673-1684.

73. Lièvre $A$, Bachet JB, Le Corre $D$, Boige $V$, Landi B, Emile JF, Côté JF, Tomasic G, Penna C, Ducreux M, Rougier P, Penault-Llorca F, Laurent-Puig P: KRAS mutation status is predictive of response to cetuximab therapy in colorectal cancer. Cancer Res 2006, 66:3992-3995.

74. National Comprehensive Cancer Network: Guidelines in Oncology: Colon Cancer. v.2. NCCN website 2009, Available at: http://www.nccn.org/ professionals/physician_gls/ PDF/ colon.pdf.

doi:10.1186/1755-8794-8-S1-S5

Cite this article as: Rasool et al:: The role of epigenetics in personalized medicine: challenges and opportunities. BMC Medical Genomics 2015 8(Suppl 1):S5

\section{Submit your next manuscript to BioMed Central and take full advantage of:}

- Convenient online submission

- Thorough peer review

- No space constraints or color figure charges

- Immediate publication on acceptance

- Inclusion in PubMed, CAS, Scopus and Google Scholar

- Research which is freely available for redistribution

Submit your manuscript at www.biomedcentral.com/submit
Ciomed Central 